SHS Web of Conferences 10, 00034 (2014)

DOI: $10.1051 /$ shsconf/20141000034

C Owned by the authors, published by EDP Sciences, 2014

\title{
Assessment of life quality factors by breast cancer patients
}

\author{
M. Pranka, A. Dzervite, R. Rungule, T. Lace, E. Miklasevics, and J. Gardovskis \\ Rīga Stradiņš University, Latvia
}

\begin{abstract}
The aim of the article is to present the results of a sociological investigation with the aim to analyze the research data on subjective and objective life quality factors for breast cancer patients and to discover the key factors influencing quality of life the most at the start of treatment. To achieve this goal a survey of 300 breast cancer patients recently having undergone a mastectomy was conducted at the Pauls Stradins Clinical University hospital. The questionnaire covered an array of social factors and a set of standardized life quality indicators. The quantitative data was supplemented with qualitative material from 14 in-depth interviews. The results showed that breast cancer patients, at the beginning of treatment, evaluated their quality of life mainly average or good. The primary factors negatively influencing quality of life were insubstantial finances, inadequate social and emotional support at the first weeks after diagnosis.
\end{abstract}

\section{Introduction}

Current medicine recognizes that it is crucial to understand and uncover social and psychological needs of patients for better results in treating illness. To understand the development of particular ailments and overall improve population health much attention is now being paid to aspects contributing to patient quality of life as well as their subjective perception and attitudes towards treatment (Adler: 2008; Antonovsky: 2001; Gray: 2003).

Cancer affects one in three of Europe's population including Latvia's inhabitants. In medicine, measurements of quality of life help to assess which treatment methods improve and which reduce a patient's quality of life; when to choose palliative and when clinical treatments. Subjective disposition and life quality evaluation is also essentially important in the process of treatment and rehabilitation of patients. Generic surveys on population quality of life (European Quality of Life Survey, 2008; EUSILC, 2010) and detailed research on general population quality of life (Bela \& Tisenkopfs, 2006; Silis, 2010) and health related quality of life for particular maladies (Kozinova \& Tomsone, 2010; Ivanovs \& Buike, 2011) have been previously conducted in Latvia. As of today, no standardized measures are being used in Latvia for evaluation of life of breast cancer patients.

This paper discusses results from a multidisciplinary research project that concentrates on investigating relations between social, genetic, clinical and treatment therapy factors influencing treatment of breast cancer patients and patients with hereditary genome mutations at the Pauls Stradins Clinical University Hospital. This paper presents data analysis on patients' subjective evaluation of life quality from data obtained in quantitative surveys and qualitative in-depth interviews. Health related

This is an Open Access article distributed under the terms of the Creative Commons Attribution License 4.0, which permits unrestricted use, distribution, and reproduction in any medium, provided the original work is properly cited. 


\section{SHS Web of Conferences}

quality of life is analysed in light of the patient subjective evaluations of key standardized factors (Testa \& Simonson, 1996; Bowling, 2005) and explained through the physical, psychological and social aspects being influenced by a person's experience, beliefs, expectations and perceptions (Urbach, 2005).

\section{Methods}

The paper is based on the results of the breast cancer patients' survey conducted (April 2010 - June 2012) at the Pauls Stradins Clinical University Hospital. All patients undergoing a mastectomy operation were invited to take part in the study. In most cases, patients consented and the survey was conducted by the researchers on the next day after surgery or later during a follow-up visit at the hospital. The universe $(\mathrm{N}=2285)$ of the target group consisted of the persons being ill with breast cancer and who have received surgical, combined and complex treatment in the survey period in Latvia (The Centre of Health Economics, 2013). The recommended sample size was 291 with the margin error 5.3\%, and the confidence level $95 \%$. The attained sample is 300. In all collected interviews, 276 respondents answered the quality of life section of the 10 page questionnaire.

Hereditary breast cancer gene carriers (14) were interviewed from May 2011 until September 2012.

The quality of life questions were modelled according to the WHOQoL-BREF measurement system (WHOQOL Group, 1998; Skevington et al 2004) and covered the four primary groups of factors: a) health and physical state, b) functional and social state, c) financial state and leisure time, d)surroundings/environmental state. Respondents were also asked to evaluate the importance of the main factors to determine their particular quality of life needs. Information is portrayed in percentages and means with confidence intervals calculated at a 95\% confidence level.

Qualitative in-depth interviews were carried out with hereditary breast cancer gene carriers from different typological groups. The sample of participants was selected from a national database that comprises data on hereditary cancer history and genetic tests for BRCA1/2 mutations. The database included 296 women identified with BRCA1 or BRCA2 genetic mutations; among those $44 \%$ of them have been treated for breast cancer, $37 \%$ treated for ovarian cancer and $19 \%$ were unaffected by cancer. The final purpose sample was created for these four health groups of women and included 4 women untouched by cancer, 7 were treated for breast cancer, 2 treated for ovarian cancer and 1 for both ovarian and breast cancer. The interviews took place at a hospital or in patients' homes. An audio recording was made of each interview and an interview guideline was used as the research instrument. The study was approved by the Ethical Committee of Riga Stradins University.

\section{Results}

\section{Respondents' profile}

The age of respondents of the quantitative survey ranged from 28 to 92 years with a mean age of 62.2, nearly half of the patients were 65 and older (47\%). $49.7 \%$ of the respondents were married or living with a partner, but among 65 and older respondents only $31.9 \%$ had a spouse and $51.1 \%$ were widowed.

Half of patients were retired and living from state pensions, while $38.3 \%$ were working, $3.7 \%$ were housewives, $2 \%$ - unemployed and $4.3 \%$ were permanently disabled. The average income per family member each month noted by the patients undergoing breast cancer surgery was 190.76LVL (Std. Deviation $\pm 95.70 \mathrm{LVL}$; Std. Error 5.74), the national average net wage in 2011 was rated at 330LVL. The state minimum consumer basket value for 2011 was $173 \mathrm{LVL}$ and average old-age pensions were only 178LVL (Central Statistical Bureau of Latvia, 2012). Among 65 and older respondents, 65.4\% (CI $\pm 7.9 \%$ ) had an average monthly income below the state minimum consumer basket, while for respondents younger than 65 a total of $40.8 \%(\mathrm{CI} \pm 7.6 \%)$ had a lower income. 
Int. Conf. SOCIETY. HEALTH. WELFARE.

Table 1. Quality of life assessment in the last 2 weeks prior to surgery - Overall, Health and Emotional state.

\begin{tabular}{|l|l|l|l|l|l|l|l|}
\hline$(N=276$, confidence level $95 \%)$ & Very bad & Bad & Partial & Good & Very good & NA \\
\hline K1.1. & $\begin{array}{l}\text { How would you } \\
\text { rate your quality } \\
\text { oflife? }\end{array}$ & $3.3 \% \pm 2.1 \%$ & $12.7 \% \pm 3.9 \%$ & $34.4 \% \pm 5.6 \%$ & $43.5 \% \pm 5.8 \%$ & $4.3 \% \pm 2.4 \%$ & $1.8 \% \pm 1.6 \%$ \\
\hline K1.2. & $\begin{array}{l}\text { How would you } \\
\text { rate your stale of } \\
\text { health? }\end{array}$ & $5.1 \% \pm 2.6 \%$ & $20.3 \% \pm 4.7 \%$ & $39.1 \% \pm 5.8 \%$ & $30.4 \% \pm 5.4 \%$ & $3.3 \% \pm 2.1 \%$ & $1.8 \% \pm 1.6 \%$ \\
\hline K1.3. & $\begin{array}{l}\text { How would you } \\
\text { rate your } \\
\text { emotional state? }\end{array}$ & $13.0 \% \pm 4.0 \%$ & $20.3 \% \pm 4.7 \%$ & $30.8 \% \pm 5.4 \%$ & $30.4 \% \pm 5.4 \%$ & $2.9 \% \pm 2.0 \%$ & $2.5 \% \pm 1.9 \%$ \\
\hline
\end{tabular}

The respondents of in-depth interviews were in the age from 26 up to 64. Four of the women were under the age of 40, five were in their forties, three were in their fifties and two were over the age of 60 .

Ten of the interviewed women were married, two had long-term partners, one was separated and one was divorced. All except three of the participants had children. Seven of the women were employed, three were housewives, one was retired, one was permanently disabled and two were unemployed. Within the sample of 14 women identified as BRCAI/2 gene mutation carriers all except 3 had a family history of cancer and only 4 had other relatives who have been tested and diagnosed with the gene mutation.

\section{Standardized indicators of quality of life}

The subjective evaluation for patients' quality of life was measured using a quantitative survey of standardized indicators as part of a larger survey covering an array of social and life-style factors influencing quality of life. The majority of the interviewed patients evaluated their quality of life as being average or good at the beginning of treatment (see Table I). One $3^{\text {rd }}$ of the respondents, prior to the treatment, evaluated their health as good, while from the three overall ratings the emotional state received the most critical evaluation. Negative factors contributing to lowered quality of life ratings were mainly linked to breast cancer patient financial and emotional state at the first weeks of treatment. Differences were observed among two main age groups - those under 65 and those 65 and older.

The following part of this article focuses on the analysis of factors which are the most influencing the quality of life after diagnosis of breast cancer. Health was rated as the most important of factors that influence the quality of life and $92.2 \%$ of patients rated it as absolutely important, yet access to health services was absolutely important only to $35 \%$ of patients. Rating their state of health in the last few weeks, $3 \%$ of patients classified their health as very good, $34.8 \%$ rated it as good, while $31.9 \%$-as bad or very bad. Majority of patients $(72.2 \%)$, prior to the of cancer diagnosis, were suffering from other chronic health problems.

When considering detailed evaluation of quality of life in four groups of factors, the highest rates were for questions referred to surroundings and environment state. More than $80 \%$ of the respondents rated each factor with the top two highest values. The lowest estimation regarding to surroundings and environment state was to accessibility of health care services where $5.2 \%$ were not at all satisfied, $8.1 \%$ a little, and $10.4 \%$ partially.

Personal relationships was the second most important factor which influences the quality of life where $84.4 \%$ (CI $\pm 4.5 \%)$ saw it as an absolute priority. Being useful to family, ability to do housework and ability to be physically active were evaluated with top most importance by more than half of the patients. A difference among the two main age groups was seen for evaluating to what extent life has meaning. It was very positive among respondents younger than 65 were $73.1 \%(\mathrm{CI} \pm 7.2 \%)$, but drastically decreased among 65 and older (only $52.7 \%$ (CI $\pm 8.5 \%$ )). 


\section{SHS Web of Conferences}

Table 2. Quality of life assessment in the last 2 weeks prior to sur gery - Health and Physical state.

\begin{tabular}{|c|c|c|c|c|c|c|c|}
\hline \multicolumn{2}{|c|}{$(N=276$, confidence level $95 \%)$} & Not at all & A little & Partially & A lot & Completely & $N A$ \\
\hline K1.4. & $\begin{array}{l}\text { To what extent } \\
\text { did physical } \\
\text { pain prevent you } \\
\text { from doing what } \\
\text { you need to do } \\
\text { every day? }\end{array}$ & $54.7 \% \pm 5.9 \%$ & $22.1 \% \pm 4.9 \%$ & $9.8 \% \pm 3.5 \%$ & $5.8 \% \pm 2.8 \%$ & $6.9 \% \pm 3.0 \%$ & $0.7 \% \pm 1.0 \%$ \\
\hline K1.5 & $\begin{array}{l}\text { How well were } \\
\text { you able to get } \\
\text { around physical!? }\end{array}$ & $2.2 \% \pm 1.7 \%$ & $7.6 \% \pm 3.1 \%$ & $9.1 \% \pm 3.4 \%$ & $12.7 \% \pm 3.9 \%$ & $68.5 \% \pm 5.5 \%$ & $0.0 \% \pm 0.0 \%$ \\
\hline K1 6. & $\begin{array}{l}\text { How satisfied } \\
\text { were you with } \\
\text { your sleep? }\end{array}$ & $9.8 \% \pm 3.5 \%$ & $13.0 \% \pm 4.0 \%$ & $20.7 \% \pm 4.8 \%$ & $29.0 \% \pm 5.4 \%$ & $26.8 \% \pm 5.2 \%$ & $0.7 \% \pm 1.0 \%$ \\
\hline K1 7. & $\begin{array}{l}\text { How much } \\
\text { did you need the } \\
\text { support of others } \\
\text { to do vmat you } \\
\text { need to do every } \\
\text { day? }\end{array}$ & $71.4 \% \pm 53 \%$ & $13.0 \% \pm 4.0 \%$ & $6.5 \% \pm 2.9 \%$ & $2.2 \% \pm 1.7 \%$ & $4.0 \% \pm 2.3 \%$ & $2.9 \% \pm 2.0 \%$ \\
\hline K1.8. & $\begin{array}{l}\text { How well } \\
\text { were you able to } \\
\text { concentrate? }\end{array}$ & $1.1 \% \pm 1.2 \%$ & $5.1 \% \pm 2.6 \%$ & $12.0 \% \pm 3.8 \%$ & $30.8 \% \pm 5.4 \%$ & $48.9 \% \pm 5.9 \%$ & $2.2 \% \pm 1.7 \%$ \\
\hline K1.9. & $\begin{array}{l}\text { Did you have } \\
\text { enough energy } \\
\text { for everyday } \\
\text { life? }\end{array}$ & $4.0 \% \pm 2.3 \%$ & $9.8 \% \pm 3.5 \%$ & $18.1 \% \pm 4.5 \%$ & $23.2 \% \pm 5.0 \%$ & $43.8 \% \pm 5.9 \%$ & $1.1 \% \pm 1.2 \%$ \\
\hline Kl.10. & $\begin{array}{l}\text { How satisfied } \\
\text { were you with } \\
\text { your physical } \\
\text { appearance? }\end{array}$ & $4.0 \% \pm 2.3 \%$ & $7.2 \% \pm 3.1 \%$ & $23.2 \% \pm 5.0 \%$ & $31.2 \% \pm 5.5 \%$ & $10.5 \% \pm 3.6 \%$ & $23.9 \% \pm 5.0 \%$ \\
\hline
\end{tabular}

Table 3. Quality of life assessment in the last 2 weeks prior to surgery - Functional and Social state.

\begin{tabular}{|c|c|c|c|c|c|c|c|}
\hline \multicolumn{2}{|c|}{ ( $N=276$, confidence level $95 \%)$} & Not at all & A little & Partially & A lot & Completely & $N A$ \\
\hline K1.11. & $\begin{array}{l}\text { How satisfied } \\
\text { were you with } \\
\text { your ability to } \\
\text { perform } \\
\text { your daily living } \\
\text { activities? }\end{array}$ & $4.3 \% \pm 2.4 \%$ & $3.3 \% \pm 2.1 \%$ & $11.2 \% \pm 3.7 \%$ & $15.6 \% \pm 4.3 \%$ & $62.7 \% \pm 5.7 \%$ & $2.9 \% \pm 2.0 \%$ \\
\hline K1.12. & $\begin{array}{l}\text { How satisfied } \\
\text { were you with } \\
\text { your capacity to } \\
\text { work to make a } \\
\text { living? }\end{array}$ & $2.2 \% \pm 1.7 \%$ & $1.1 \% \pm 1.2 \%$ & $5.4 \% \pm 2.7 \%$ & $8.7 \% \pm 3.3 \%$ & $31.5 \% \pm 5.5 \%$ & $51.1 \% \pm 5.9 \%$ \\
\hline K1.13. & $\begin{array}{l}\text { To what extent } \\
\text { did you feel } \\
\text { your life to be } \\
\text { meaningful? }\end{array}$ & $2.2 \% \pm 1.7 \%$ & $2.5 \% \pm 1.9 \%$ & $7.2 \% \pm 3.1 \%$ & $17.0 \% \pm 4.4 \%$ & $63.4 \% \pm 5.7 \%$ & $7.6 \% \pm 3.1 \%$ \\
\hline Kl.14. & $\begin{array}{l}\text { How satisfied } \\
\text { were you with } \\
\text { yourself? }\end{array}$ & $2.9 \% \pm 2.0 \%$ & $1.1 \% \pm 1.2 \%$ & $21.4 \% \pm 4.8 \%$ & $26.8 \% \pm 5.2 \%$ & $37.0 \% \pm 5.7 \%$ & $10.9 \% \pm 3.7 \%$ \\
\hline K1.15. & $\begin{array}{l}\text { How satisfied } \\
\text { were you with } \\
\text { your personal } \\
\text { relationships? }\end{array}$ & $0.4 \% \pm 0.7 \%$ & $2.2 \% \pm 1.7 \%$ & $5.4 \% \pm 2.7 \%$ & $22.1 \% \pm 4.9 \%$ & $50.4 \% \pm 5.9 \%$ & $19.6 \% \pm 4.7 \%$ \\
\hline Kl.16. & $\begin{array}{l}\text { How satisfied } \\
\text { were you with } \\
\text { the support you } \\
\text { got from your } \\
\text { family and } \\
\text { friends? }\end{array}$ & $1.4 \% \pm 1.4 \%$ & $2.2 \% \pm 1.7 \%$ & $7.2 \% \pm 3.1 \%$ & $14.9 \% \pm 4.2 \%$ & $72.8 \% \pm 5.2 \%$ & $1.4 \% \pm 1.4 \%$ \\
\hline
\end{tabular}

The following part of this article focuses on the analysis of factors that are the most influencing the quality of life of patients after diagnosis of breast cancer where quality of life factors have been explained additionally through qualitative interview material. 
Int. Conf. SOCIETY. HEALTH. WELFARE.

Table 4. Quality of life assessment in the last 2 weeks prior to surgery - Financial state and Leisure time.

\begin{tabular}{|l|l|l|l|l|l|l|l|}
\hline$(N=276$, confidence level 95\%) & Not at all & A little & Partially & A lot & Completely & NA \\
\hline K1.17. & $\begin{array}{l}\text { To what extent } \\
\text { did your } \\
\text { financial } \\
\text { situation meet } \\
\text { your needs? }\end{array}$ & $8.0 \% \pm 3.2 \%$ & $12.7 \% \pm 3.9 \%$ & $28.3 \% \pm 5.3 \%$ & $38.4 \% \pm 5.7 \%$ & $12.7 \% \pm 3.9 \%$ & $0.0 \% \pm 0.0 \%$ \\
\hline K1.18 & $\begin{array}{l}\text { How available to } \\
\text { you was the } \\
\text { information } \\
\text { you need in your } \\
\text { daily life? }\end{array}$ & $0.0 \% \pm 0.0 \%$ & $1.4 \% \pm 1.4 \%$ & $4.0 \% \pm 2.3 \%$ & $15.2 \% \pm 4.2 \%$ & $76.4 \% \pm 5.0 \%$ & $2.9 \% \pm 2.0 \%$ \\
\hline K1.19. & $\begin{array}{l}\text { How much did } \\
\text { you enjoy life? }\end{array}$ & $15.9 \% \pm 4.3 \%$ & $7.2 \% \pm 3.1 \%$ & $17.4 \% \pm 4.5 \%$ & $30.4 \% \pm 5.4 \%$ & $14.1 \% \pm 4.1 \%$ & $14.9 \% \pm 4.2 \%$ \\
\hline K1.20. & $\begin{array}{l}\text { To what extent } \\
\text { did you have the } \\
\text { opportunity for } \\
\text { leisure } \\
\text { activities? }\end{array}$ & $25.4 \% \pm 5.1 \%$ & $7.2 \% \pm 3.1 \%$ & $14.5 \% \pm 4.2 \%$ & $26.1 \% \pm 5.2 \%$ & $10.5 \% \pm 3.6 \%$ & $16.3 \% \pm 4.4 \%$ \\
\hline
\end{tabular}

Table 5. Quality of life assessment in the last 2 weeks prior to surgery- Surroundings and Environment.

\begin{tabular}{|c|c|c|c|c|c|c|c|}
\hline \multicolumn{2}{|c|}{$(N=276$, confidence level $95 \%)$} & Not at all & A little & Partially & A lot & Completely & $N A$ \\
\hline Kl.21. & $\begin{array}{l}\text { How satisfied } \\
\text { were you with } \\
\text { the conditions of } \\
\text { your living } \\
\text { place? }\end{array}$ & $1.1 \% \pm 1.2 \%$ & $2.5 \% \pm 1.9 \%$ & $9.1 \% \pm 3.4 \%$ & $20.3 \% \pm 4.7 \%$ & $65.2 \% \pm 5.6 \%$ & $1.8 \% \pm 1.6 \%$ \\
\hline $\mathrm{K} 1.22$. & $\begin{array}{l}\text { How safe do } \\
\text { you feel in your } \\
\text { daily life? }\end{array}$ & $2.9 \% \pm 2.0 \%$ & $2.9 \% \pm 2.0 \%$ & $6.9 \% \pm 3.0 \%$ & $18.8 \% \pm 4.6 \%$ & $67.4 \% \pm 5.5 \%$ & $1.1 \% \pm 1.2 \%$ \\
\hline $\mathrm{K} 1.23$. & $\begin{array}{l}\text { How healthy } \\
\text { is your physical } \\
\text { environment? }\end{array}$ & $0.7 \% \pm 1.0 \%$ & $2.9 \% \pm 2.0 \%$ & $5.4 \% \pm 2.7 \%$ & $20.7 \% \pm 4.8 \%$ & $68.1 \% \pm 5.5 \%$ & $2.2 \% \pm 1.7 \%$ \\
\hline K1.24. & $\begin{array}{l}\text { How satisfied } \\
\text { are you with } \\
\text { your access to } \\
\text { health services? }\end{array}$ & $3.6 \% \pm 2.2 \%$ & $5.1 \% \pm 2.6 \%$ & $10.9 \% \pm 3.7 \%$ & $15.2 \% \pm 4.2 \%$ & $64.5 \% \pm 5.6 \%$ & $0.7 \% \pm 1.0 \%$ \\
\hline $\mathrm{K} 1.25$. & $\begin{array}{l}\text { How satisfied } \\
\text { are you with } \\
\text { your access to } \\
\text { transportation? }\end{array}$ & $2.9 \% \pm 2.0 \%$ & $4.0 \% \pm 2.3 \%$ & $6.5 \% \pm 2.9 \%$ & $9.1 \% \pm 3.4 \%$ & $75.0 \% \pm 5.1 \%$ & $2.5 \% \pm 1.9 \%$ \\
\hline
\end{tabular}

\section{Discussion}

\section{Only the sick go to see a doctor}

The Eurobarometer (2012) value survey, conducted in the spring of 2013, showed that Europeans see health as the most important factor for their happiness (75\%), followed by love (41\%). (pg. 15). The same is noted by our survey. But while health is of the utmost importance for most patients' life quality, the respondents admitted that they don't undergo regular mammography and gynaecological checkups. Despite to the fact they are aware that regular health check-ups can reduce the risk of cancer, the majority of respondents visit doctor only when they are encountered with the influence of the disease or if there are serious health problems. Interviewed patients expressed general confusion regarding available diagnostics and distrust of medical intervention.

"In a way I let it go - I really didn't want there to be anything, when I visited the oncologist after my gynecologist sent me. He asked me - how do you feel? Well, how could I feel? Nothing was hurting. He said that there is something there, but then - don't worry, come back after half a year. [...] His attitude was so careless. As I wanted to hear that there is nothing wrong, so I left his office with a light heart. If I had known then that you can puncture and take a biopsy, I would have done it, if there was a suggestion like this!"” (MK, 48). 


\section{SHS Web of Conferences}

Accessibility of health care services, like in the quantitative survey, is evaluated low by the respondents of in-depth interviews. Waiting for several months for state financed medical examinations that cost generally 1-7 LVL was noted. Alternatively, patients could pay extra to get treatment faster, yet many could not afford it. After surgery, patients undergoing further therapy noted expenses of 50-70 LVL a month on treatment, for many which is nearly half or a third of the monthly income.

is one of the reasons patients noted as the reason of avoiding medical examinations and treatment is the attitude of medical personnel and state of medical facilities. Patients point the lack of support and involvement from general practitioners (locally known as family doctors) and gynecologists.

"She isn't a family doctor; I don't know what she is. A family doctor has to be more versatile and that's why she can't have so many patients at one time. She is a pharmaceutical trader, a middleman, that's what she could be" (LS, 61).

\section{Looks aren't everything}

Complete satisfaction with their outer appearance was rated by only $11 \%$ with $1 / 4$ of patients not wanting or being able to give an answer. Significant difference is linked with age and level of health prior to the surgery, among patients, $\leq 44$ the importance of outer appearance was rated the highest with $20 \%$ being completely satisfied, while for patients $\geq 65$, more than one third chose not to answer this question. The outer appearance as a completely important factor for quality of life after a mastectomy operation was rated by more than half (52\%) of patients 44 and younger, but the importance declines for each subsequent older group. Patients have a choice to undergo reconstructive surgery after a mastectomy, but the expenses regarding the income level are too high, and the physical distortion put emotional strain on younger women.

"He (boy-friend) accepts me as I am, but in quiet he has mentioned that I could have the reconstruction done. Of course, who doesn't want a woman lying next to him with both breasts? We have talked about this, we have discussed that it is a difficult operation and that right now it costs a lot of money" (SM, 44).

\section{The need for social and emotional support}

For most women, the diagnosis of breast cancer, especially at the beginning of treatment, was unanticipated and leads to a great need for emotional support. The stress leading up to treatment was clearly reflected in the quantitative survey results, $13 \%$ of patients rated their emotional state two weeks before surgery as very low. Personal relationships were one of the most important factors influencing quality of life of the patients with $84.4 \%$ seeing it as an absolute priority. Completely satisfied with support from family and friends were $72.8 \%$ of interviewed patients.

The need for positive personal relationships and emotional support was stressed by in-depth interviews.

"The most important - contact with other people," If you are alone, you get more depressed. We need a lot of contact. I need to believe and to live a very calm life - no worries" (TV, 53).

"It is important to have the sort of way of life and relationships with people that enable you to preserve peace with oneself and others. From day to day, it's important to see the people around you who understand and support you, help to reduce stress. Optimism is what helps" (VK, 52).

As the top most importance the ability to do housework and ability to be physically active was rated by more than half of the patients $(71.7 \% ; 69.7 \%)$. Positive evaluation was common for functional and social state, half of the patients were completely satisfied about their abilities to do everyday tasks $(62.7 \%)$, keep up personal relationships $(50.4 \%)$ and find meaning in their lives $(63.4 \%)$. 
Int. Conf. SOCIETY. HEALTH. WELFARE.

\section{Financial state, employment and leisure}

Financial state and leisure time were the factor groups with the lowest ratings in quantitative research. With nearly half of the patients being retired and the average income per family member barely above the state minimum consumer basket value, the financial situation was completely satisfactory for $12.7 \%$, while $20.7 \%$ pf respondents were not at all or a little satisfied with their finances. Yet financial status does not influence quality of life equally for all patients, differences in importance can be seen by age groups. Older patients put a lot less significance on finances with only $38.8 \%$ of patients $\geq 75$ rating it as a priority, but finances as the utmost important for quality of life rated $78.3 \%$ by among those $\leq 44$. At the same time, financial well-being is one of the main drivers of care for health for elderly even if they put greater value in family ties (Silis, 2010). Additional expenses are required for breast cancer patients' treatment and diet: to finance co-payments for surgery, medical examinations, and prescription drugs, and, at the same time, trying to implement a healthy diet, pay utility bills and travel expenses. In many cases, a patient's income per capita was just above the poverty level and they did not qualify for financial social assistance.

"It is a choice between dying or getting treatment, there are only two options. If you work, then you're fine. But if you don't work, and have to survive only on 100 Lats, then that's it. It is simply a mockery of people. In fact, I can only cover my utility bills with this money. Now I have a hard choice - to get treatment, or to pay my utility bills. The state has put me in a dead end to choose whether I'm undergoing medical treatment, taking care of my health, not paying my utilities, put myself in debt or skip treatment and die soon" (SM, 44).

If the household has been granted the status of low-income, the cancer patients are in a better position than patients whose incomes are just slightly above the specified level for financial support. About $16 \%$ of the patients were not able to enjoy their life in the last few weeks prior to undergoing treatment and a total of $25.4 \%$ noted that opportunity for leisure activities was not at all available to them. Patients were often still working in the weeks leading up to surgery, they were responsible for the household and didn't have the financial means to spend on entertainment.

"No, I can't go to the theatre, I can't drive where I want to, can't go and see my friend. If I go to visit friends, I must bring something for their table, [...] bring a gift. [...] So then I don't go anywhere, I have to deny myself many things, because I don't have the money" $(K R, 40)$.

\section{Changes in quality of life}

When considering the previous two weeks prior to the interview, the most frequent evaluation for overall quality of life was good, in total $47.8 \%$ of answers, while the next most likely answer was neither bad nor good with $34.4 \%$. Still, $16 \%$ of the respondents in total perceived their quality of life being bad or very bad.

There has been much research done on chronic illness leading to patient biographical disruption (Bury, 1982; Lawton, 2003) as well as accepting illness as normal in situations of general hardship (Pound et al., 1998; Williams, 2000). Especially for older people, health problems are expected and accepted as normal (Sanders, 2002), but in some cases the addition of cancer to other existing health problems can heighten the disruptive experience (Sinding \& Wiernikowski, 2008).

Nevertheless, the in-depth interviews showed that following the diagnosis of cancer, patients, due to their emotional vulnerability and physical impairment, were faced with re-evaluating and changing relationships with family and friends.

"He worked, he was tired, but that I might be tired, no one was interested. ... Because of this disease I came to a better, a higher understanding of life, that I need to value myself higher, that I had low self-appreciation, that I have to live on my own and that I need peace right now. ... [to live] in a sort of calm. I chose to live alone, we separated" (SM, 44). 


\section{SHS Web of Conferences}

Patients also re-examined their lifestyles after initial treatment, and showed that it lead to more attention being paid to diet, fitness and spirituality.

"[...] it's important what you eat, how you live, and relationships, you have to change it all. Eating and movement. [...] I try to eat those seasonal fruits, apples, berries when I have a garden, just everything fresh. The immunologist is the only one that advises to pay attention to this, but not precisely, you have to [figure it out] yourself" (LS, 61).

After the oncological diagnosis, interviewed patients had to undergo surgery, as well as chemotherapy and/or radiation therapy. As a result, patients' state of physical capabilities deteriorated, complicating their work duties. Among the patients interviewed in-depth, 5 were already unemployed for a long period with limited opportunities to find a job or simply to choose to be housewives, 2 had switched to working part-time and switched to a less stressful line of work, and 1 was on long-term sick leave.

"I go to the State Employment Agency. I have appointments there regularly, I get some information, I was offered a job in a nursing home, but I do not have enough strength to take care of them. Options are limited because I regularly go to check-ups, and because I have this diagnosis"(TV, 53).

\section{Conclusions}

At the beginning of treatment, the interviewed breast cancer patients generally rate their quality of life as being average or good. Negative factors contributing to lowered quality of life are mainly linked to their financial, social and emotional state at the first weeks of treatment. The improvement of these factors for patients can be addressed at a national and medical facility level. Over time, it could be possible to improve financial support for patients undergoing breast cancer treatment, with prolonged sick leave and treatment coverage, and improve patients' awareness of the illness and diagnosis so that it can be treated at an earlier stage with lower expenses.

Due to the fact that many individuals have not experienced any symptoms and have undergone regular medical check-ups, the diagnosis of cancer came to many as a shock. The primary issue that can be addressed by medical staff at the early treatment stages is to support patients and improve their quality of life. Moral support should be available from the primary surgeon, family physician and nursing staff, or, alternatively, patients should be directed to a psychological councilor. There is also a need to improve availability of verified and expert approved information about the illness, treatment options and financial support. The lack of public awareness of the necessity to participating in the breast cancer screening program has been noted by the Cabinet of Ministers which has decreed an oncology illness control program during 2009-2015 that is aimed at improving primary prophylactics, national cancer screening, treatment, palliative care and methodical surveillance of the field (The Cabinet of Ministers of the Republic of Latvia, 2011). When trying to evaluate different types of treatment and quality of life correlations, it is essential to take into account differences among age groups. Divergent factors are at play in influencing quality of life for older and younger patients. All age groups place health and personal relationships as priorities for their quality of life, yet when it comes to physical function, outer appearance, finances, leisure and the environment importance varies depending on respective age groups.

This research project is financially supported by the European Social Fund (2009/0230/1DP/1.1.1.2.0/09/APIA/VIAA/070).

\section{References}

[1] Adler N. E., Page A. E. K. ed. (2008) Cancer care for the whole patient: Meeting psychosocial health needs. Washington, D.C.: The National Academies Press. 
Int. Conf. SOCIETY. HEALTH. WELFARE.

[2] Antonovsky, A. (2001) Putting patients first: Designing and practicing patient centred care. San Francisco: Jossey-Bas.

[3] Bela B., Tisenkopfs T. (ed.) (2006) Dzīves kvalitāte Latvijā [Quality of life in Latvia]. (in Latvian) Riga: Zinatne.

[4] Bowling A. (2005). Measuring Health: A Review of Quality of Life Measurement Scales. 3rd ed. Maidenhead: Open University Press.

[5] Bury, M. (1982). “Chronic illness as biographical disruption.” Sociology of Health \& Illness, 4(2), 167-82.

[6] EU-SILC (2010) Survey on Income and Living Condition. Central Statistical Bureau of Latvia, Retrieved May 28, 2012. http://www.csb.gov.lv/en/notikumi/population-s-self-assessment-stateheath-2010-32003.html (Accessed: 20.04.2013.)

[7] European Quality of Life Survey (2009), European Foundation for the Improvement of Living and Working Conditions, Office for Official Publications of the European Communities, Dublin, pg.107.

[8] Gray D., Packham C. (2003) "Need for redefining needs.” Health \& Quality Life Outcomes 1:3.

[9] Ivanovs A., Buike I. (2011) Latvijas iedzīvotāju ar veselību saistīiās dz̄̄ves kvalitātes (SF-36v2) pētijjuma rezultāti [Latvian inhabitant health related quality of life (SF-36v2) research results] (abstract in Latvian). In: Riga Stradins University 2011 Scientific conference, Riga: 201104 , 14-15. p71.

[10] Kozinova O., Tomsone S. (2010) Quality of life comparison of persons with mental disorders living in different social care facilities [abstract in Latvian]. In: Riga Stradins University 2011 Scientific conference, Riga: 2010 March 18-19. p42.

[11] Lawton, J. (2003). "Lay experiences of health and illness: Past research and future agendas." Sociology of Health \& Illness, 25(3), 23-40.

[12] Silis V. (2010) Health behavior and quality of life of Latvian population. PhD thesis. Riga: Riga Stradins University.

[13] Sinding C., Wiernikowski J. (2008) "Disruption foreclosed: older women's cancer narratives." Health: An Interdisciplinary Journal for the Social Study of Health, Illness and Medicine, Vol 12(3): 389 -411.

[14] Skevington S.M., Lotfy M., O'Conell K.A. (2004) The World Health Organization's WHOQOLBREF quality of life assessment: Psychometric properties and results of the international field trial. A Report from the WHOQOL Group' Quality of Life Research 13(1998): 299-310.

[15] Testa M.A., Simonson D.C. (1996) 'Assessment of quality-of-life outcomes' The New England journal of Medicine 334:13, 835-840.

[16] The Cabinet of Ministers of the Republic of Latvia (2011) Public health guidelines 2011-2017. Order Nr. 504, October 5, 2011. Retrieved May 10, 2012.

[17] http://phoebe.vm.gov.lv/misc_db/web.nsf/626e6035eadbb4cd85256499006b15a6/ ba89d22083b17edac22575a6002bb060/\$FILE/SVP_2011_2017.pdf (Accessed: 20.04.2013.)

[18] Urbach D.R. (2005) 'Measuring Quality of Life After Surgery' Surgical Innovation 12(2): 161165.

[19] Williams, S.J. (2000). "Chronic illness as biographical disruption or biographical disruption as chronic illness? Reflections on a core concept." Sociology of Health \& Illness, 22(1), 40-67.

[20] WHOQOL Group (1998) "The World Health Organization Quality of Life Assessment" (WHOQOL). Development and psychometric properties. Social Science \& Medicine 46:15691585.

[21] Central Statistical Bureau of Latvia online database:

[22] Minimum consumer basket per capita (in lats), updated 13.03.2012.

[23] http://www.csb.gov.lv/en/minimum-consumer-basket-capita-lats (Accessed: 20.04.2013.)

[24] Social Security - Key Indicators, updated 08.07.2010. 


\section{SHS Web of Conferences}

[25] http://www.csb.gov.lv/en/statistikas-temas/social-security-key-indicators-30686.html (Accessed: 20.04.2013.)

[26] Personal Income - Key Indicators, updated 13.02.2012.

[27] http://www.csb.gov.lv/en/statistikas-temas/personal-income-key-indicators-30630.html (Accessed: 20.04.2013.)

[28] Slimību profilakses un kontroles centrs. Statistikas dati par pacientu skaitu sadalījumā pa reìioniem, lokalizācijas veidiem, dzimuma un vecuma grupām no 2009. gada līdz 2012. gadam. The Centre of Health Economics. Onkology. Statistical data on patients in regional, localization kinds, gender and age groups distribution 2009 - 2012. http://www.spkc.gov.lv/veselibasaprupes-statistika/ (Accessed: 08.05.2013.)

[29] The Values of Europeans. Standard Eurobarometer 77. Spring 2012 Report. pg. 15. Available at: http://ec.europa.eu/public_opinion/archives/eb/eb77/eb77_value_en.pdf. (Accessed: 20.04.2013.) 